University of Nebraska - Lincoln

DigitalCommons@University of Nebraska - Lincoln

June 2001

\title{
Analysis of the Financial Assurance Plan in the License Application for a Low-Level Radioactive Waste Disposal Facility
}

\author{
F. Gregory Hayden \\ University of Nebraska - Lincoln, ghayden1@unl.edu \\ Scott Fullwiler \\ University of Missouri-Roll
}

Follow this and additional works at: https://digitalcommons.unl.edu/cbafacpub

Part of the Business Commons

Hayden, F. Gregory and Fullwiler, Scott, "Analysis of the Financial Assurance Plan in the License Application for a Low-Level Radioactive Waste Disposal Facility" (2001). College of Business Faculty Publications. 7.

https://digitalcommons.unl.edu/cbafacpub/7

This Article is brought to you for free and open access by the Business, College of at DigitalCommons@University of Nebraska - Lincoln. It has been accepted for inclusion in College of Business Faculty Publications by an authorized administrator of DigitalCommons@University of Nebraska - Lincoln. 


\title{
Analysis of the Financial Assurance Plan in the License Application for a Low-Level Radioactive Waste Disposal Facility
}

\author{
F. Gregory Hayden \\ and
}

Scott T. Fullwiler

Our purpose is to evaluate the efficiency of the financial assurance plan in the license application ' submitted by American Ecology Corporation (AEC) to site, design, and build a new technological facility in Boyd County, Nebraska, for the disposal of low-level radioactive waste (LLRW). Efficiency means the ability to accomplish desired effects. Thus, efficiency considerations begin with social beliefs and ethics in order to know what is desirable. "Ethics can be considered a system of guidance designed to assist in living within a society.... That we must live together installs the positive requirement of doing good for one another" (Anderson and Englehardt 2001, 6-7). Humans in a social system are immersed in obligation to one another (8). "Ethics seeks to resolve the problems of what is harm and what is help and to unravel the complexities of moral choice" (9). In a socioeconomic system, choices and decisions are about organizational actions. "Action is behavior under the governance of some larger understanding ..." (9).

For sodality, a society is immersed in obligations, rules, and requirements which force decision makers to determine ethical actions. This requires decision makers to complete efficiency evaluations in order to make judgments based on criteria drawn from social beliefs. As the court stated in Ohio v. Interior, efficiency means "the result that achieves the greatest value to society" (1989). The efficiency criteria applied here

The authors are, respectively, Professor of Economics, University of Nebraska-Lincoln, and Assistant Professor of Economics, University of Missouri-Rolla. This paper was presented at the annual meeting of the Association for Evolutionary Economics, New Orleans, Louisiana, USA, January 5-7, 2001. 
are the legal criteria that have been codified by national and state laws, rules, and regulations; judicial decisions; and corporate contracts.

\section{Level of Financial Assurance for Corrective Action or Cleanup}

According to the Nuclear Regulatory Commission, financial assurance is required to cover costs associated with any corrective action or cleanup of real or personal property on or off site if a release of a radioactive material occurs during the operative life, closure, stabilization, or institutional control (CRF 10. 61, Subpart E). Paul Smith provided guidance and a model for how to evaluate the adequacy of finances planned for particular corrective actions and cleanups (1993). The Nebraska Department of Environmental Quality (NDEQ) converted AEC's application into Smith's model, creating a database that can be utilized to make an assessment of the adequacy of cost estimates for corrective actions and cleanups for three particular eventualities: premature vault failure, flooding, and cancer.

With regard to waste vault failures, AEC assumed there will be no vault failure for the first fifty years. Beyond that period, the estimated cost for vault repair as presented in the application is in table 1. AEC did not indicate or explain how the costs were determined, which is inconsistent with the requirements of the National Environmental Protection Act (Mandelker 1984). However, it is clear from the information in table 1 that the level of estimated funds needed is inadequate. For example, if the facility were to become operational five years from 1998, eighty years of operations would be eighty-five years from 1998. If inflation, at 4 percent per year, is taken into consideration, and the $\$ 13,100,000$ for the repair in 2083 of a vault to contain $B$ and $C$ radioactive waste is discounted to the present, it is equal to $\$ 467,130$ in 1998 . It is not credible that a failed B/C vault could be repaired for only $\$ 467,130$ in 1998 ; thus, the $\$ 13,100,000$ is a vast underestimation. That number is even less credible when it is realized that the repair estimate is to include the high cost of relocating the $\mathrm{B} / \mathrm{C}$ waste to another location.

\section{Table 1. Estimated Cost of Failed Vault Repair}

Period in Years after

Class A Waste Vault

Class B/C Waste Vault

Operations Begin

\begin{tabular}{rrr}
\hline $51-70$ & $\$ 3,100,000$ & $\$ 13,100,000$ \\
$71-90$ & $3,100,000$ & $13,000,000$ \\
$91-110$ & $3,100,000$ & $13,000,000$ \\
$11-135$ & $3,100,000$ & $13,100,000$ \\
\hline
\end{tabular}

Source: NDEQ 1998, 194, table A-4. 
The same lack of credibility exists with respect to the cost of vault repair for class A waste. The estimate for the year 2083 to repair a class A vault is $\$ 3,100,000$ (table 1). That would mean the estimated cost for repairing the class A vault in 1998 is only $\$ 110,542$. Not believable!

As presented in table 1, AEC assumed that the cost of vault repair remains constant for eighty-four years after year 51 . This is not credible because inflation will continue. In addition, as the vaults age, the deterioration rate will increase, thereby inducing higher probabilities for vault failure. Thus, each year in the future, repair will be more expensive.

AEC's financial plan further reduced the already inadequate vault repair cost to $\$ 26,000$ by applying to the inadequate cost figure presented above a percentage probability that full vault repair would not be undertaken at all (NDEQ 1998, 194, table A-4). According to this assumption, AEC needs to plan to provide only $\$ 26,000$ for use during the period seventy-one to ninety years from the time operations began. Accounting for inflation alone, at 4 percent, means the estimate of $\$ 26,000$ that is to be available for vault repair 85 years from 1998 is $\$ 927.13$ valued in 1998 dollars. That is not credible! It was assumed, for example, that the chance that AEC would ever repair the $\mathrm{B} / \mathrm{C}$ waste vault if it failed was 50 percent, or less. The application of such probability coefficients is inconsistent with legal requirements found in Title 194 (NDEQ 1994) and Title 180 (NHHSS 1994) regarding remedial action as well as health and safety. Failed vaults are to be repaired. A program is to be developed "for the regulation of disposal of low-level radioactive waste based on a zero-release objective" (Neb. Rev. Stat. § 81-1599).

In addition to the probabilities that LLRW vaults would not be repaired if they fail, the application further reduced the already inadequate estimate of vault repair by not providing for the full cost. The original inadequate estimates are further reduced by the application of the coefficients in table 2. Both Title 194 (NDEQ 1994) and CFR 10.61 clarify that an applicant's cost estimates for corrective action or cleanup are to be sufficient to cover the total cost. Title 194 and CFR 10.61 do not allow a .008 proba-

\section{Table 2. Coefficient to Estimate Portion of Cost to Have Available for Repair}

Period in Years after

Class A Waste Vault

Class B/C Waste Vault

Operations Begin

\begin{tabular}{rll}
\hline $51-70$ & .006 & .004 \\
$71-90$ & .008 & .006 \\
$91-110$ & .018 & .004 \\
$111-135$ & .050 & .025 \\
\hline
\end{tabular}

Source: NDEQ 1998, 194, table A-3. 
bility coefficient (see table 2) for remedial action for the period of seventy-one through ninety years. There is a required probability coefficient of 100.0 .

The cost estimates due to floods suffered the same underestimation of cost and misuse of probability explained with regard to vault failure. In addition, the probability of occurrence for a flood in AEC's financial plan was inconsistent with hydrograph data for the site as provided by AEC to the NDEQ. The facility is to be built in a wetland, which increases the vault's chances of being flooded, increases its deterioration rate, and increases the probability that any vault repair will need to include the expense of groundwater treatment.

As with vault failure, the financial plan for cancer treatment underestimated cost and applied probability percentages that are not consistent with CFR 10.61 and Titles 180 and 194. In addition, the cost estimates were not sufficient to provide cancer care for all patients. It was assumed that the cancer rates will be at the highest industry frequency and that one-third of injured workers will be workers who contract cancer in their lifetime (NDEQ 1998, 194, table A-2). Yet, because the application assumed a cancer latency period of fifteen years for workers, it was projected that only 80 percent of the workers with cancer will file suit (table A-1). It was further assumed that only 25 percent of the 80 percent will receive any financial assistance. That assistance is further limited to an average award of $\$ 300,000$ throughout the 137-year period, completely ignoring inflation (table A-1). These assumptions are all inconsistent with the requirement for full compensation (NDEQ 1994).

\section{Adequacy of Financial Assurance for Different Scenarios}

According to Title 194, financial assurance must be provided to cover costs associated with (1) all licensed activities to be conducted over the facility's operating life of up to thirty years, (2) facility closure and stabilization of seven years, (3) custodial care activities of a hundred years, and (4) any corrective action or cleanup of real or personal property on or off site if a release of radioactive material occurs during the operating life, the closure/stabilization period, or the institutional control period (NDEQ 1994, chapter 6). The purpose of this section is to assess the ability of AEC to meet these requirements through analysis of three possible scenarios of AEC's application. $^{2}$

\section{Institutional Control Fund}

The first scenario (see table 3) is for the institutional control fund which is also intended to provide funding for the remedial action fund. AEC is to make an initial cash deposit of $\$ 7,895,000$ when the construction loan is finalized at the beginning of the first year (year 0 of column 1 ). It is to be repaid during the second through the tenth 


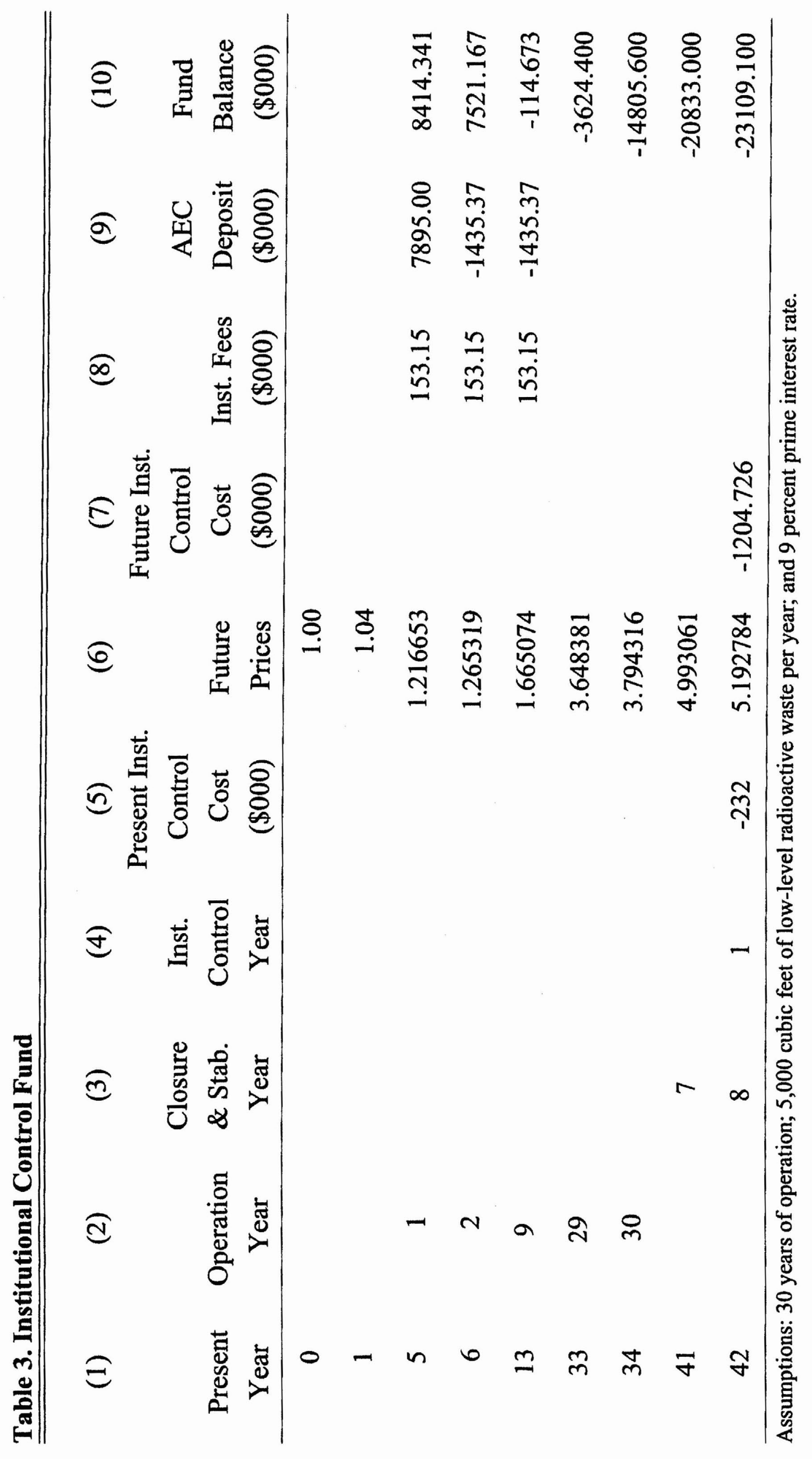


years of operation with a disposal fee of $\$ 30.63$ per cubic foot levied during the first ten years of operation. The levy is to generate funds to (1) repay the initial deposit, (2) transfer $\$ 11$ million to the remedial action fund at the end of the last year of operation, and (3) generate sufficient funds, when placed at interest to pay the cost of custodial care.

The scenario in table 3 is for thirty years of operation (column 2), with a LLRW stream of 5,000 cubic feet per year, ${ }^{3}$ and an interest rate of 9 percent to repay the $\$ 7,895,000$. Column 1 contains the years of the process from design to the end of institutional control in year 141, with only selected years presented in table 3 . Column 2 indicates the years of operation, column 3 the years of closure and stabilization, and column 4 the years of institutional control. Column 5 is $\$ 232,000$ (in current dollars) of annual cost shown in the application's worksheets for maintenance during the institutional control period. When adjusted for inflation at 4 percent (as assumed in the application) with the future price index in column 6 , the cost for each year is found in column 7 . It was to have been paid by the balance in column 10 ; however, the balance in column 10 is negative for year 1 of institutional control. ${ }^{4}$

Column 8 is the annual levy of $\$ 30.63$ for each of the 5,000 cubic feet of LLRW beginning with the first year of operation (column 2) through the tenth year. It is $\$ 153,150$ per year. Column 9 contains the original deposit of $\$ 7,895,000$ in year 1 of operations. In operating years 2 through 10 are the payments of $\$ 1,435,370$ per year necessary to reimburse AEC for the original deposit plus interest of 9 percent per annum, the assumed prime rate. ${ }^{5}$

Column 10 is the sum of columns 8 and 9 plus the appropriate interest received. In the first year of operation, AEC assumed an interest rate of 4.55 percent will be received on the $\$ 153,150$ in column 8 . For years 2 through 10 , the interest rate is 2.47 percent because, as the waste is received at the facility throughout the year, an amount equal to only one-half of the $\$ 153,150$ fee could, on average, be invested for each year. An interest rate of 4.55 is also applied to the $\$ 7,895,000$ in the first year. The interest rate earned on the balances in column 10 is 5 percent.

As demonstrated in column 10, the fund for institutional control becomes negative in year 9 of operation. Thus, it is not possible to (1) repay the initial deposit, (2) have funds available for institutional control (pay costs in column 7), or (3) be able to make the $\$ 11,000,000$ deposit to the remedial fund in the final (thirtieth) year of operations. Very early (thirteenth year) in the 142-year scenario, the deficit begins and continues to build to a negative $\$ 14,805,600$ in the last (thirtieth) operating year and to a negative $\$ 23,109,100$ in the first year of institutional control.

\section{Remedial Action Fund}

The remedial action fund (see table 4 ) is to be funded by a transfer of $\$ 11$ million from the institutional control fund in the thirtieth year of operation and by levied 


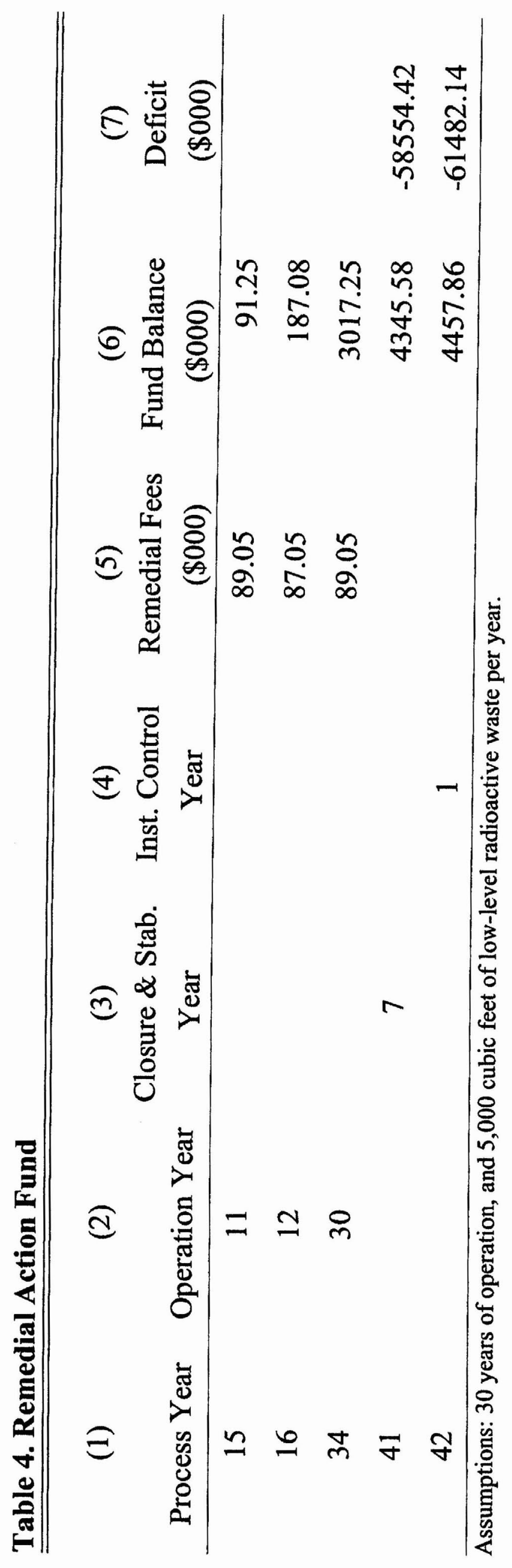


disposal fees of $\$ 17.81$ per cubic feet of waste received during the eleventh through the thirtieth years of operation, in order to generate adequate funds for possible remedial action. These two sources are to accumulate and grow with interest to a total of $\$ 62,800,000$ at the end of the last year (seventh) of closure and continue to accumulate interest through year 141 at 5 percent per year.

The remedial scenario is expressed in table 4 under the assumptions of thirty years of operation and LLRW of 5,000 cubic feet per year. The levy of $\$ 17.81$ for 5,000 cubic feet is $\$ 89,050$ per year for years 11 through 30 of operations (column 5) with interest received at 2.47 percent per annum. The balance in column 6 receives an interest payment of 5 percent per year. As explained above, the $\$ 11$ million is not available from the institutional control fund to be deposited in year 30 of operation. Thus, the $\$ 11$ million increase that would have been expected in that year is not included in column 6 . This means that the remedial fund has only $\$ 4,245,580$ at the end of the seventh year of closure. This is $\$ 58,554,420$ deficient of the required $\$ 62,800,000$. That deficiency will continue to grow the entire period through the 141 st year of the process.

\section{Facility Closure and Stabilization Fund}

The closure and stabilization fund is to be initially funded with $\$ 23$ million deposited by AEC when the construction loan is finalized in year 0 (column 1, table 5), plus a levied disposal fee of $\$ 94.06$ per cubic foot of LLRW during the first eleven years of operation. The purpose is to generate sufficient funding for closure and stabilization of the facility after operation. The scenario is found in table 5 .

The $\$ 470,300$ in column 7 of table 5 is the charge levied on the annual waste stream of 5,000 cubic feet at $\$ 94.06$ per cubic foot. It is added to the original deposit of $\$ 23,000,000^{6}$ (column 8) for the first year of operation to arrive at the sum in column 9. ${ }^{7}$ The repayment of the $\$ 23$ million loan at a prime rate of 9 percent in 10 payments of $\$ 4,181,300$ each during the second through tenth years of operation is found in column 8. It is subtracted from the levied total in column 7 for those years.

Since column 8 is larger than column 7, the balance intended to provide for closure and stabilization begins to decrease in the second year of operation. In the ninth year of operation the fund (column 9) becomes a negative $\$ 760,421,000$. Therefore, it cannot pay off the initial loan and cannot provide expenditures for closure costs, even during the first year of closure (column 3 ) when the balance in column 9 is a negative $\$ 27,079,900$.

Column 4 is the application's estimated yearly cost for closing the facility during the seven years of closure. Those estimates are in current dollars, and therefore, are increased by the future price index for a 4 percent inflation rate in column 5 to determine the total cost in column 6 . That amount, for example, the cost of $\$ 7,914,000$ (column 6) in the final (seventh) year of closure, is to be paid from the fund balance, but 


\begin{tabular}{|c|c|c|c|c|c|c|c|c|}
\hline (1) & (2) & (3) & (4) & (5) & (6) & (7) & (8) & (9) \\
\hline ProcessYear & $\begin{array}{c}\text { Operation } \\
\text { Year }\end{array}$ & $\begin{array}{l}\text { Closure \& } \\
\text { Stab. Year }\end{array}$ & $\begin{array}{c}\text { Present Inst. } \\
\text { Control Cost } \\
(\$ 000)\end{array}$ & Future Prices & $\begin{array}{l}\text { Future Inst. } \\
\text { Control Cost } \\
(\$ 000)\end{array}$ & $\begin{array}{c}\text { Inst. Fees } \\
(\$ 000)\end{array}$ & $\begin{array}{c}\text { AEC } \\
\text { Deposit } \\
(\$ 000)\end{array}$ & $\begin{array}{l}\text { Fund Balance } \\
\qquad(\$ 000)\end{array}$ \\
\hline 0 & & & & 1.00 & & & & \\
\hline 1 & & & & 1.04 & & & & \\
\hline 5 & 1 & & & 1.216653 & & 470.3 & 23000 & 23470.300 \\
\hline 6 & 2 & & & 1.265319 & & 470.3 & -3711 & 20932.820 \\
\hline 7 & 3 & & & 1.315932 & & 470.3 & -3711 & 6210.548 \\
\hline 13 & 9 & & & 1.665074 & & 470.3 & -3711 & -760.421 \\
\hline 35 & & 1 & -3995 & 3.946089 & -15764.6 & & & -27079.900 \\
\hline 36 & & 2 & -37441 & 4.103933 & -153665.0 & & & -182089.000 \\
\hline 41 & & 7 & -1585 & 4.993061 & -7914.0 & & & -272936.000 \\
\hline
\end{tabular}

Assumptions: 30 years of operation; 5000 cubic feet of low-level radioactive waste per year; and 9 percent interest rate. 
that is impossible because the balance is a negative $\$ 272,936,000$ (column 9) in that year. $^{8}$

\section{Concluding Remarks}

AEC's license application does not meet the efficiency criteria with regard to particular corrective actions or the adequacy of funds. The funds would be more inadequate if the years of operation are less than the maximum of thirty years because there would be fewer years to collect levies. Furthermore, it is not possible to compensate for the inadequate revenue by increasing the fee charged per cubic foot because the disposal facility is a monopoly, thus the demand is elastic (a positive marginal revenue) and a price increase would decrease revenue.

As Marc R. Tool explained: "Examination permits reflection on the character of the consequences and upon their bearing on future events" $(1979,288)$. This examination demonstrated that the consequences that could be expected from AEC's financial assurance plan cannot be consistent with established social criteria. Thus, the plan is not efficient.

\section{Notes}

1. The application was submitted by AEC's wholly owned subsidiary, U.S. Ecology. The title of the application is "Safety Analysis Report."

2. All 142 years of 17 different scenarios are available upon request from the authors.

3. Numerous databases and projection studies indicate that the annual LLRW stream to be expected will be less than 5,000 , thus making the monetary flow from fees more insufficient than indicated here.

4. AEC allocated 2.47 percent less than what is to be spent because of interest to be earned, and 5 percent is earned on everything not spent. Thus, $[-20833-(1204.727 / 1.0247)][1.05]=$ $-231091$.

5. An important note is the fact that, although the $\$ 7,895,000$ is deposited in year 0 of the scenario, there is no indication in the application of any interest charges or interest earned for the funds during the first five years prior to facility operation. Given its adverse financial condition, AEC would have to borrow the funds, thus the $\$ 7,895$ million principal should have been continuously reduced each year by an additional annual interest charge of 4 percent ( 9 percent -5 percent). Had this been done for years 0 through 4 , the balance in column 10 would have become deficient earlier than demonstrated in table 3 .

6. As with the institutional control fund, the application made no mention of interest charges or payments on the deposit in the five years prior to operations.

7. For some unstated reason, AEC did not include interest earnings here.

8. AEC allocated 5 percent less than what is to be spent because of interest to be earned on everything not spent. The balance in column 9 for year 34 is $-\$ 10776.5$. Thus $[-10776.5-$ $(15764.6 / 1.05)][1.05]=-27079.0$. 


\section{References}

Anderson, James A., and Elaine E. Englehardt. The Organizational Self and Ethical Conduct. Fort Worth: Harcourt College Publishers, 2001.

Code of Federal Regulations (CFR). Chapter 10, Section 61.

Mandelker, Daniel R. NEPA Law and Litigation: The National Environmental Policy Act. Wilmette, Illinois: Callaghan \& Company, 1984.

Nebraska Department of Environmental Quality (NDEQ). Title 194 Rules and Regulations for the Disposal of Low-Level Radioactive Waste. Lincoln, Nebraska: State of Nebraska, 1994.

Nebraska Department of Environmental Quality. Response to Comments: Issues and Responses. Lincoln, Nebraska: State of Nebraska, 1998.

Nebraska Health and Human Services System (NHHSS). Title 180 - Regulations for Control of Radiation-lonizing. Lincoln, Nebraska: State of Nebraska, 1994.

Nebraska Revised Statutes. [ 81-1599.

Smith, Paul. A Process for Establishing a Financial Assistance Plan for LLW Disposal Facilities. DOE/ LLW-139. Idaho Falls, Idaho: US Department of Energy Field Office, 1993.

Tool, Marc R. The Discretionary Economy: A Normative Theory of Political Economy. Santa Monica, Calif.: Goodyear Publishing Company, Inc., 1979.

State of Ohio v. US Department of the Interior. 880 F.2d 432 (D.C. Cir. 1989). 